\title{
Trace Elements and Radionuclides in Brazil Nuts from the Brazilian Amazon
}

\author{
Ariane Kluczkovski*(Corresponding Author), Maristela Martins, Ellon Lobo, José G. de M. \\ Junior, Pedro H. Campelo, Tamires Oliveira, Vinícius D. G. T. Martins \\ Federal University of Amazonas, Brazil
}

Received: May 19, 2020

Accepted: June 10, 2020

Published: June 15, 2020

doi:10.5296/jas.v8i2.17185

URL: https://doi.org/10.5296/jas.v8i2.17185

\begin{abstract}
The Brazil nut tree (Bertholletia excelsa) is an accumulating plant and, as such, absorbs metals from the soil according to the different geographic regions in which it is found. In this context, some Brazil nuts can exceed the safe level of certain trace elements and thus become toxic to consumers. To provide risk assessment information, the aim of this study was to evaluate trace elements and radionuclides found in Brazil nuts from the Brazilian Amazon. Trace elements were evaluated using ICP-MS, however $\mathrm{As}, \mathrm{Ca}, \mathrm{Cr}, \mathrm{Mg}, \mathrm{Hg}$ and $\mathrm{Pb}$ were not detected. The levels of Fe, $\mathrm{Zn}$ and Ti were within the maximum levels stipulated for Dietary Reference Intake. The results provide preliminary data concerning the surveillance of antimony ( $\mathrm{Sb}$ ) in the samples analyzed. Further studies are necessary to evaluate the bioavailability of Sb and other metals, and the Se mechanisms for detoxifying Sb. Concerning radionuclides, the committed effective dose was below the established limits by UNSCEAR (2000). In conclusion, the levels of trace elements and radionuclides in the samples did not levels that could be considered toxic to human health.
\end{abstract}

Keywords: Bertholletia excelsa, radioactivity, radium, zinc

\section{Introduction}

Among nuts most consumed by the world's population, the Brazil nut (Bertholletia excelsa) is known as an excellent source of proteins and minerals and thus provides health benefits (Rita Cardoso et al., 2016; Yang, 2009). The Brazil nut tree is a large tree in the Amazon rainforest and has the capacity to absorb a significant amount of minerals from the soil, of which selenium (Se) is the primary mineral. This element has already been extensively studied in nuts from different regions and several studies have proven that the different levels of Se are related to geographical conditions (Chang, Gutenmann, Reid, \& Lisk, 1995; Pacheco \& Scussel, 2007). Due to its high mineral content, some authors have suggested the daily ingestion of two Brazil nuts to benefit from the antioxidant properties (Thomson, Chisholm, McLachlan, \& Campbell, 2008). 


\section{Macrothink

However, several studies report the presence of trace elements and radionuclides that must be studied to calculate the risks associated with human consumption of Brazil nuts. Radionuclides and heavy metals are chemical elements present in the environment through naturally occurring geochemical processes, or as products of industrial or agricultural emissions, deposition, and disturbances (Mitrovic et al., 2019). Knowledge of the range end concentration of radionuclides in the diet is necessary to be able to quantify the risk of exposure. This knowledge allows us to identify emerging long-term trends of contamination, and thus enables possible mitigation before contamination becomes a significant health risk (Pearson et al., 2016). The estimation of risk to humans through ingestion requires understanding of the pathways by which the radionuclides are eventually ingested. Some of radionuclides such as $226 \mathrm{Ra}, 210 \mathrm{Po}, 210 \mathrm{~Pb}$ in the soil are incorporated into the plants and find their way into the food chain (Chandrashekara \& Somashekarappa, 2016). On the other hand, trace elements, or micronutrients, are important for health in all stages of life and deficiencies of these substances are linked to several pathologies and, as such, can reduce the quality of life of the population (Höller et al., 2018). According to Albuquerque et al. (2020), these elements can be divided into two groups: toxic elements ( $\mathrm{As}, \mathrm{Cd}, \mathrm{Hg}, \mathrm{Pb}$ ) and essential trace elements (Co, Cu, Cr, Fe, Mn, Mo, Ni, Se, Zn).

The presence of metals can occur not only due to contamination of the origin, but also due to inadequate practices, such as the use of chemical agents, such as pesticides in the planting environments and in vehicles, as well as inadequate storage. Besides the metals, some radionuclides are present in Brazil nuts such as radium ( $\mathrm{Ra}$ ) and barium (Ba) (Hiromoto et al., 1996; Venturini \& Sordi, 1999). For these elements, the risk of consumption should be calculated by means of the committed effective dose, which evaluates their propensity to compromise health, since the ingestion of radioactive foods is associated with greater risks of occurrence of cancer (Balonov, 2008; Celik, Cevik, Celik, \& Kucukomeroglu, 2008).

Given the above, the objective of this study was to evaluate the content of heavy metals and radionuclides in Brazil nuts from the Brazilian Amazon and compare them with the minimum permissible daily doses indicated by various health control agencies.

\section{Materials and Methods}

\subsection{Materials}

Samples of shelled Brazil nuts of different sizes from suppliers from various regions of the municipality of Óbidos in the State of Pará, Brazil, were obtained between 2015 and 2017. In each yearly harvest, three samples were collected and evaluated. The region in which the samples were obtained is presented in Figure 1. 


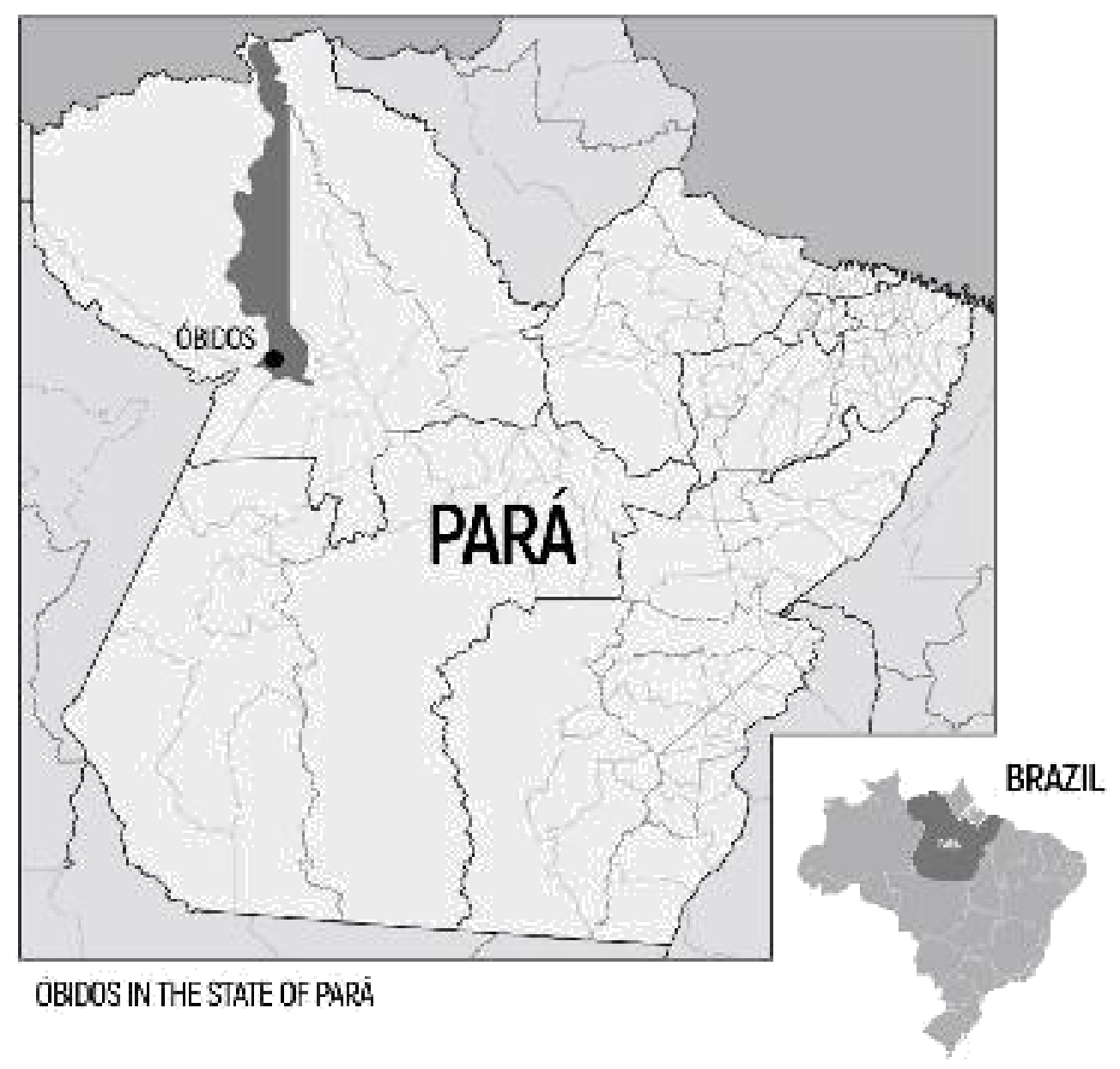

Figure 1. Map of the region where sampling was undertaken.

\subsection{Methods}

\subsubsection{Trace Elements}

The samples were evaluated for arsenic (As), cadmium $(\mathrm{Ca})$, cromium $(\mathrm{Cr})$, copper $(\mathrm{Cu})$, iron $(\mathrm{Fe})$, mercury $(\mathrm{Hg})$, magnesium $(\mathrm{Mg})$, lead $(\mathrm{Pb})$, antimony $(\mathrm{Sb})$, titanium $(\mathrm{Ti})$, zinc $(\mathrm{Zn})$ and barium $(\mathrm{Ba})$ radionuclides. Brazil nuts were triturated in a processor with stainless steel blades and a polypropylene body to homogenize the samples. The samples were digested in nitric acid and the concentration of each metal in the samples was measured using Inductive Coupled Plasma-Mass Spectrometry (ICP-MS), according to AOAC methodology (2016).

\subsubsection{Radionuclides}

The radionuclides were determined using gamma spectrometry $\left({ }^{226} \mathrm{Ra},{ }^{228} \mathrm{Ra},{ }^{210} \mathrm{~Pb}\right)$. For uranium detection, colorimetric reactions were performed with arzenazo III and, after the extractions, the spectrophotometric measurement of the complex at $650 \mathrm{~nm}$ was carried out; Thorium: reaction with arzenazo III, after extractions and spectrophotometric measurement of the complex at $665 \mathrm{~nm}$. The standards used were as follows: 
${ }^{210} \mathrm{~Pb}: \mathrm{N} .27 \mathrm{~L} 16$ (LNMRI- IRD N.

C/019/A16); ${ }^{226}$ Ra:n. 28L16 (LNMRI- IRD N. C/025/A16); ${ }^{228}$ Ra:n. 4339b (NIST N.

SRM4339b); Uranium Reference Standard N ICP-MS-66N-0.1X-1 (AccuStandard N.

3164); Thorium Reference Standard N ICP-MS-61N-0.1X-1 (AccuStandard N. 3159).

\subsubsection{Committed Effective Dose}

Dose calculations per unit of intake are provided by the International Commission on Radiological Protection (ICRP). The potential of the radiological impact due to the consumption of contaminated food is evaluated using the calculation of the committed effective dose (CED), given by Equation 1:

Equation. 1

$$
\operatorname{DEC}\left(S v \cdot a^{-1}\right)=e(g) \times A \times T_{c}
$$

In which: e (g) is the committed effective dose per unit of intake, or effective dose coefficient; A is the average radionuclide activity, and $\mathrm{Tc}$ is the annual consumption rate of the given food.

The values for the effective dose coefficient [e (g)] are based on models and metabolic data used by the United Nations Scientific Committee's evaluation (UNSCEAR, 2000). The effective dose coefficients for this study were defined by the IAEA (1996).

\subsubsection{Statistics}

Student's t-test was used to compare the committed effective doses with the established maximum limit.

\section{Results and Discussion}

\subsection{Trace Elements and Consumption}

Minerals and trace elements were found in the samples. In order to evaluate the impact of the levels of metals in relation to daily consumption, the values of dietary reference intakes (DRI) (Institute of Medicine, 2002) were used. Table 1 shows the results of the samples as the average of the values found. In the three harvests, $\mathrm{As}, \mathrm{Cd}, \mathrm{Cr}, \mathrm{Mg}, \mathrm{Hg}$ and $\mathrm{Pb}$ were not detected in the samples studied. The concentrations of all trace elements found are presented in Figure 2. In another study, Souza, Vieira, \& Oliveira (2009) analyzed Brazil nut samples from markets in the same state in which we obtained our samples and reported the content of As $=27 \mu \mathrm{g} . \mathrm{kg}^{-1}$. On the other hand, in the samples we found, $\mathrm{Cu}=17.1, \mathrm{Fe}=21.3$ and $\mathrm{Zn}=70.36 \mathrm{mg} \cdot \mathrm{kg}^{-1}$, higher values than those found by Santos et al. (2013) in fresh Brazil nuts from the same state, with levels of 14.0 and 29.6 and $35.1 \mathrm{mg} \cdot \mathrm{kg}^{-1}$, respectively. 


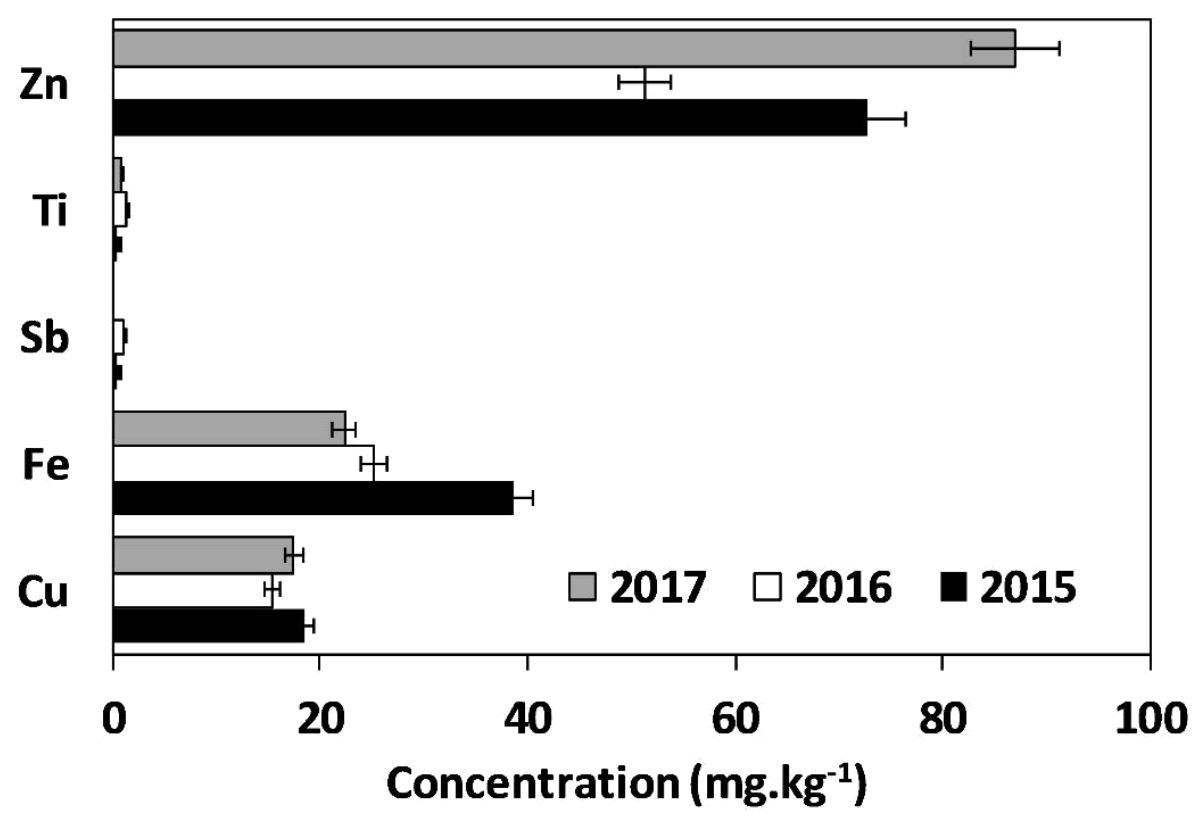

Figure 2. Trace elements found in Brazil nuts from the state of Pará, Brazil during three harvests (2015-2017)

Table 1. Trace elements in Brazil nuts versus consumption

\begin{tabular}{lccc}
\hline Elements $^{\mathrm{a}}$ & Brazil nut* $^{*}$ & $\begin{array}{c}\text { DRI (per day) } \\
\text { RDA }^{\mathrm{b}}\end{array}$ & $\mathrm{UL}^{\mathrm{d}}$ \\
\hline Arsenic $(\mathrm{As})$ & $\mathrm{ND}^{\mathrm{e}}$ & $\mathrm{NR}^{\mathrm{f}}$ & $\mathrm{NR}$ \\
Cadmium $(\mathrm{Ca})$ & $\mathrm{ND}$ & $\mathrm{NR}$ & $\mathrm{NR}$ \\
Chromium $(\mathrm{Cr})$ & $\mathrm{ND}$ & $35 \mathrm{mg}$ & $\mathrm{ND}$ \\
Copper $(\mathrm{Cu})$ & $17.1 \pm 1.63$ & $900 \mu \mathrm{g}$ & $10 \mathrm{mg}$ \\
Iron(Fe) & $21.73 \pm 18.0$ & $8 \mathrm{mg}$ & $45 \mathrm{mg}$ \\
Mercury $(\mathrm{Hg})$ & $\mathrm{ND}$ & $\mathrm{NR}$ & $\mathrm{NR}$ \\
Magnesium $(\mathrm{Mg})$ & $\mathrm{ND}$ & $420 \mathrm{mg}$ & $350 \mathrm{mg}$ \\
Lead $(\mathrm{Pb})$ & $\mathrm{ND}$ & $\mathrm{NR}$ & $\mathrm{NR}$ \\
Antimony $(\mathrm{Sb})$ & $0.55 \pm 0.56$ & $\mathrm{NR}$ & $\mathrm{NR}$ \\
Titanium $(\mathrm{Ti})$ & $0.85 \pm 0.42$ & $\mathrm{NR}$ & $\mathrm{NR}$ \\
Zinc $(\mathrm{Zn})$ & $70.36 \pm 17.9$ & $11 \mathrm{mg}$ & $40 \mathrm{mg}$ \\
\hline
\end{tabular}

*The results are expressed in average \pm standard deviation; ${ }^{\mathrm{a}}$ Elements expressed in $\mathrm{mg} . \mathrm{kg}^{-1} ;{ }^{\mathrm{b}}$ Data from (Institute of Medicine, 2002), DRI for adults; ${ }^{c}$ RDA: Recommended Dietary Allowance; ${ }^{\mathrm{d}}$ UL: Tolerable Upper Intake Level; ${ }^{\mathrm{e}}$ N.D: not detected in the following limit of quantification (LQ): As $=<0.006$; $\mathrm{Ca}:<0.006 ; \mathrm{Cr}:<0.045 ; \mathrm{Mg}:<0.006 ; \mathrm{Pb}:<0.01 ; \mathrm{Sb}:<0.045$; $\mathrm{Hg}:<0.01$; ${ }^{\mathrm{f}} \mathrm{NR}$ : Not reported.

The Fe content (21.3 mg. $\left.\mathrm{kg}^{-1}\right)$ found in the samples was lower than that cited by Moodley et al. (2007) (74.26 mg.kg ${ }^{-1}$ ), but it still meets the DRI, as presented in Table 1. This suggests that the Brazil nuts from this region can be a source of this element, which is a component of hemoglobin and several enzymes, and acts in the prevention of anemia. However, for 
consumers who adopt the vegan diet, and who use the Brazil nut as a source of Fe, it is necessary to observe the recommendation of the Institute of Medicine (2002) which states that the absorption of non-heme iron is lower for those consuming vegetarian diets than for those eating non-vegetarian diets. Therefore, it has been suggested that the iron requirement for those consuming a vegetarian diet is approximately 2- fold greater than for those consuming a non-vegetarian diet. It is also nutritionally important to confirm the presence of $\mathrm{Cu}$ in Brazil nuts, since it is involved in the oxidation mechanism and its deficiency leads to disorders in the oxidative metabolism of the organism. The level found (17.1 mg. $\left.\mathrm{kg}^{-1}\right)$ was close to that reported by Rodushkin, Engström, Sörlin, \& Baxter (2008), who analyzed two Brazil nut samples purchased at in retail stores with values of $\mathrm{Cu}=22$ and $23 \mathrm{mg} \cdot \mathrm{kg}^{-1}$. The level of $\mathrm{Cu}$ was below that reported as being able to cause toxic effects, such as gastrointestinal disorder and liver damage. The samples studied had originally come from a native forest area, in the State of Pará, which naturally presents $\mathrm{Zn}$ and $\mathrm{Cu}$ contents, as observed in the study by Guerreiro et al. (2017).

Environmental and soil contamination by $\mathrm{Cu}$ can occur through the application of copper sulphate in the crop area, due to Cu's fungicidal and bactericidal properties. Nevertheless, the levels found were below the value of $19.6 \mathrm{mg} \cdot \mathrm{kg}^{-1}$, as reported in other studies (Welna, Klimpel, \& Zyrnicki, 2008). As for the Zn content (70.36 mg.kg-1), it was close to $92.8 \mathrm{mg} \cdot \mathrm{kg}^{-1}$, as reported by other authors (Naozuka, Marana, \& Oliveira, 2010). The presence of Zn may be beneficial and suggests the need for further studies on the organic or inorganic form in which $\mathrm{Zn}$ is present in the nut, in order to reinforce the concept that the nut is a source of this mineral in the diet. $\mathrm{Zn}$ is an important component of metalloenzymes and may be associated with the functions of DNA and RNA polymerases and act on cell replication.

The level of antimony ( $\mathrm{Sb}$ ) ranged from 0.541-1.130 mg. $\mathrm{kg}^{-1}$. The WHO (2006) tolerable daily intake (TDI) for $\mathrm{Sb}$ is $6 \mu \mathrm{g} /$ bodyweight per day, and the nuts from some of the regions sampled presented levels to support the consumption of 3 nuts per day as suggested in previous work concerning $\mathrm{Sb}$. There is no health organization recommendation for $\mathrm{Sb}$ in Brazil nuts, but potential risks to human health can occur. In conclusion, it is possible to affirm that the levels of the elements evaluated are not toxic to human health, considering the recommended daily consumption of Brazil nuts.

Further studies are necessary to evaluate the bioavailability of $\mathrm{Sb}$ and other metals, and the Se mechanisms for detoxifying $\mathrm{Sb} . \mathrm{Hg}$ and $\mathrm{Pb}$ were not detected. On the other hand, Rodushkin et al. (2008) found Sb levels of 1.2 and $1.7 \mathrm{mg} \cdot \mathrm{kg}^{-1}$ respectively but did not mention the region of origin of the two samples that were analyzed. The same authors cited the presence of Ti, at levels of 8.9 and $8.4 \mu \mathrm{g} . \mathrm{kg}^{-1}$, which differ in relation to the present study, since the average of the three harvests was $0.85 \mathrm{mg} . \mathrm{kg}-1$.

Even though the presence of titanium is beneficial in the soil for the development of plants, monitoring Ti content is still important, (Lyu et al., 2017).I In food production it is used in the form of an additive (titanium dioxide) and, in this context, there may be a need to monitor toxic levels that effect human metabolism.

The various studies cited so far show that Brazil nut samples from the same Brazilian region 
present different results regarding trace elements. This corroborates the data on the differences between the content of Se in nuts, as mentioned by Silva Junior et al. (2017). The authors state there are differences among the soils of the Brazil nut producing regions, and therefore it is not certain that the daily consumption of two nuts provides the antioxidant effect, since during the processing, the lots of several regions are mixed to form a single batch. As for the undetected elements, this can be explained by the lack of their presence in the soil in the studied regions, since the samples came from communities where the soil of the Amazon Rainforest has no history of pesticide use, which contaminates the soil with the heavy metals in its composition.

\subsection{Radionuclides}

Data on natural radioactivity in foods are scarce for comparison with the results, but Martins et al. (2012) found levels of $104.8^{226} \mathrm{Ra}$ and $99.5^{228} \mathrm{Ra}$, which are higher than our findings. On the other hand, Parekh et al. (2008) reported levels of ${ }^{226} \mathrm{Ra}\left(31 \pm 1 \mathrm{~Bq} \cdot \mathrm{kg}^{-1}\right)$ and ${ }^{228} \mathrm{Ra}\left(33 \pm 1 \mathrm{~Bq} \cdot \mathrm{kg}^{-1}\right)$ which are lower than the values found in the present study. The ${ }^{226} \mathrm{Ra}$ values found in this study were like those reported by Turner, Radley, \& Mayneord (1958) with levels of $66.6 \mathrm{~Bq} \cdot \mathrm{kg}^{-1}$. The results for radionuclides are presented in Table 2.

Table 2. Radionuclides in Brazil nut samples from the state of Pará, Brazil

\begin{tabular}{cr}
\hline Radionuclides & Activity $\left(\mathrm{Bq} \cdot \mathrm{kg}^{-1}\right)^{*}$ \\
\hline $226_{\mathrm{Ra}}$ & $67.19 \pm 1.51$ \\
$228_{\mathrm{Ra}}$ & $68.7 \pm 2.04$ \\
\hline
\end{tabular}

*The results are expressed in average \pm standard deviation

Armelin (2016) evaluated 20 samples purchased in retail stores in several cities of Brazil between 2010 and 2013 and assumed, as a basis for calculation, a per capita consumption of $1.5 \mathrm{~kg}$ per year. For the analysis of the risk associated with Brazil nut consumption, the effective doses were estimated for the ${ }^{226} \mathrm{Ra}$ and ${ }^{228} \mathrm{Ra}$ radionuclides. The annual consumption of nuts was estimated based in the rate observed by the Brazilian Institute of Geography and Statistics (IBGE, 2011) and the cluster diets of the World Health Organization (WHO, 2006). For the comparison between these two estimates and the maximum limit established in the legislation, the Student's t test was applied, according to Table 3. 
Table 3. Comparison of the effective committed dose for the ${ }^{226} \mathrm{Ra}$ and ${ }^{228} \mathrm{Ra}$ radionuclides in Brazil nuts based on different annual consumption rates

\begin{tabular}{|c|c|c|c|c|c|c|c|}
\hline \multirow[b]{2}{*}{ Radionuclides } & \multicolumn{3}{|c|}{ IBGE $(2011)^{\mathrm{a}}$} & \multicolumn{3}{|c|}{ Cluster Diets $^{\mathrm{b}}$} & \multirow[b]{2}{*}{$p^{f}$} \\
\hline & $\begin{array}{l}\text { CED } \\
(\mu \text { Sv.a- } 1)\end{array}$ & Value* & Range $^{\mathrm{e}}$ & $p^{f}$ & Value* & Range & \\
\hline${ }^{226} \mathrm{Ra}$ & 6.30 & $1.379 \pm 0.005$ & $1.374-1.384$ & $<0.0001$ & $0.016 \pm 0.000$ & 0 & $<0.0001$ \\
\hline${ }^{228} \mathrm{Ra}$ & 11.00 & $3.366 \pm 0.013$ & $2.356-2.380$ & $<0.0001$ & $0.028 \pm 0.000$ & 0 & $<0.0001$ \\
\hline
\end{tabular}

*The results are expressed in average \pm standard deviation. a Annual consumption rates obtained from the Brazilian Institute of Geography and Statistic (IBGE, 2011); ${ }^{\text {b }}$ Rates of annual consumption according to World Health Organization (WHO, 2006); ${ }^{\mathrm{c}}$ Maximum committed effective dose by intake established by (UNSCEAR, 2000) (adults); ${ }^{\mathrm{d}}$ Mean committed effective dose \pm standard deviation; ${ }^{e}$ range of the committed effective dose; ${ }^{f}$ p-value.

It was found that the estimated committed doses present significant differences between themselves for radionuclides ( $\mathrm{p}<0.0001$ ), and based on the results it is possible to state that for both consumption conditions the effective doses of the radionuclides are below the reference values established by UNSCEAR (2000). Hiromoto et al. (1996) analysed commercial Brazil nut samples to determine the number of natural radionuclides and the rate of radiological risk resulting from ingestion by the population. The values observed by the authors were $1.4 \pm 0.4$ $\mathrm{Bq} . \mathrm{kg}^{-1}$ for ${ }^{238} \mathrm{U} ; 26.3 \pm 4.1 \mathrm{~Bq} \cdot \mathrm{kg}^{-1}$ for ${ }^{226} \mathrm{Ra} ; 4.71 .8 \mathrm{~Bq} \cdot \mathrm{kg}^{-1}$ for ${ }^{210} \mathrm{~Pb} ; 16.5 \pm 4.3 \mathrm{~Bq} \cdot \mathrm{kg}^{-1}$ for ${ }^{232} \mathrm{Th}$ and $31.3 \pm 6.4 \mathrm{~Bq} \cdot \mathrm{kg}^{-1}$ for ${ }^{228} \mathrm{Th}$. These values resulted in a maximum effective dose per year of $0.20 \mathrm{mSv}$ per person, considering that a person will eat at most $100 \mathrm{~g}$ of Brazil nut per week. Brazil nut trees present high barium adsorption from soil, explaining the high concentrations in the nuts (Hiromoto et al., 1996; Martins et al., 2012).

\section{Conclusion}

As the analyzed elements were within the limits recommended for food consumption, it is possible to affirm that the trace elements in Brazil nuts from the sampled regions can play the expected role in food for the prevention of diseases and not toxicity. Consumers who adopt a vegan diet should be aware of the use of Brazil nuts as a possible source of Fe and $\mathrm{Zn}$, besides Se. The radionuclide levels found showed that the effective committed doses of radionuclides in the samples are below the reference values and therefore safe for consumption. However, more studies need to be done on samples from regions in the Western Amazon, as well as in regard to the relationship between trace elements and radionuclides in soil and the levels obtained from different sites. Studies on different harvests should also present the effect of the climatic variations in the Amazon region, principally regarding the pluviometry indices, since this factor affects the absorption of the trace elements by the Brazil nut tree. Such data may provide subsidies for the better protection of native Brazil nut trees and the resulting production chain, as well as contributing to the correct calculation of basal needs in regard to the daily ingestion of Brazil nuts. 


\section{References}

AOAC. (2016). Official methods of analysis. (A. of O. A. Chemists, Ed.) (19th ed.). Maryland: AOAC.

Armelin, M. J. A. (2016). Activity levels of gamma-emitters in Brazil nuts. Brazilian Journal of Radiation Sciences, 4(1). https://doi.org/10.15392/bjrs.v4i1.200

Balonov, M. (2008). Exposures from environmental radioactivity: international safety standards. Applied Radiation and Isotopes, 66, 1546-1549.

Celik, N., Cevik, U., Celik, A., \& Kucukomeroglu, B. (2008). Determination of indoor radon and soil radioactivity levels in Giresun, Turkey. Journal of Environmental Radioactivity, 99(8), 1349-1354. https://doi.org/10.1016/j.jenvrad.2008.04.010

Chang, J. C., Gutenmann, W. H., Reid, C. M., \& Lisk, D. J. (1995). Selenium content of Brazil nuts from two geographic locations in Brazil. Chemosphere, 30(4), 801-802. https://doi.org/10.1016/0045-6535(94)00409-N

Guerreiro, Q. L. de M., Júnior, R. C. de O., dos Santos, G. R., Ruivo, M. L. P., Beldini, T. P., Carvalho, E. J. M., ... Santos, P. R. B. (2017). Spatial variability of soil physical and chemical aspects in a Brazil nut tree stand in the Brazilian Amazon. African Journal of Agricultural Research, 12(4), 237-250. https://doi.org/10.5897/AJAR2016.11766

Hiromoto, G., Oliveira, J., Carvalho, J. S., Vicente, R., \& Bellintani, S. A. (1996). Collective Dose and Risk Assessment from Brazil Nut Consumption. Radiation Protection Dosimetry, 67(3), 229-230. https://doi.org/10.1093/oxfordjournals.rpd.a031822

Höller, U., Bakker, S. J. L., Düsterloh, A., Frei, B., Köhrle, J., Konz, T., ... Rezzi, S. (2018). Micronutrient status assessment in humans: Current methods of analysis and future trends. TrAC Trends in Analytical Chemistry, 102, 110-122. https://doi.org/10.1016/j.trac.2018.02.001

IAEA, I. A. E. A. (1996). International Basic Safety Standards for Protection Against Ionizing Radiation and for the Safety of Radiation Sources.

IBGE, I. B. de G. e E. (2011). Pesquisa de orçamentos familiares 2008-2009:análise do consumo alimentar pessoal no Brasil. Rio de Janeiro: IBGE. Institute of Medicine, U. (2002). Dietary reference intakes for vitamin $A$, vitamin $K$, arsenic, boron, chromium, copper, iodine, iron, manganese, molybdenum, nickel, silicon, vanadium, and zinc. (U. Institute of Medicine, Ed.) (First). Washington: National Academies Press.

Lyu, S., Wei, X., Chen, J., Wang, C., Wang, X., \& Pan, D. (2017). Titanium as a Beneficial Element for Crop Production. Frontiers in Plant Science, 8. https://doi.org/10.3389/fpls.2017.00597

Martins, M., Pacheco, A. M., Lucas, A. C. S., Andrello, A. C., Appoloni, C. R., \& Xavier, J. J. M. (2012). Brazil nuts: determination of natural elements and aflatoxin. Acta Amazonica, 42(1), 157-164. https://doi.org/10.1590/S0044-59672012000100018

Moodley, R., Kindness, A., \& Jonnalagadda, S. B. (2007). Elemental composition and 
chemical characteristics of five edible nuts (almond, Brazil, pecan, macadamia and walnut) consumed in Southern Africa. Journal of Environmental Science and Health, Part B, 42(5), 585-591. https://doi.org/10.1080/03601230701391591

Naozuka, J., Marana, S. R., \& Oliveira, P. V. (2010). Water-soluble Cu, Fe, Mn and Zn species in nuts and seeds. Journal of Food Composition and Analysis, 23(1), 78-85. https://doi.org/10.1016/j.jfca.2009.08.003

Pacheco, A. M., \& Scussel, V. M. (2007). Selenium and Aflatoxin Levels in Raw Brazil Nuts from the Amazon Basin. Journal of Agricultural and Food Chemistry, 55(26), 11087-11092. https://doi.org/10.1021/jf072434k

Parekh, P. P., Khan, A. R., Torres, M. A., \& Kitto, M. E. (2008). Concentrations of selenium, barium, and radium in Brazil nuts. Journal of Food Composition and Analysis, 21(4), 332-335. https://doi.org/10.1016/j.jfca.2007.12.001

Rita Cardoso, B., Apolinário, D., da Silva Bandeira, V., Busse, A. L., Magaldi, R. M., Jacob-Filho, W., \& Cozzolino, S. M. F. (2016). Effects of Brazil nut consumption on selenium status and cognitive performance in older adults with mild cognitive impairment: a randomized controlled pilot trial. European Journal of Nutrition, 55(1), 107-116. https://doi.org/10.1007/s00394-014-0829-2

Rodushkin, I., Engström, E., Sörlin, D., \& Baxter, D. (2008). Levels of inorganic constituents in raw nuts and seeds on the Swedish market. Science of The Total Environment, 392(2-3), 290-304. https://doi.org/10.1016/j.scitotenv.2007.11.024

Silva Junior, E. C., Wadt, L. H. O., Silva, K. E., Lima, R. M. B., Batista, K. D., Guedes, M. C., ... Guilherme, L. R. G. (2017). Natural variation of selenium in Brazil nuts and soils from the Amazon region. Chemosphere, 188, 650-658. https://doi.org/10.1016/j.chemosphere.2017.08.158

Souza, M. G., Vieira, E. C., \& Oliveira, P. V. (2009). Determinação de As, Cd e Pb em amêndoas e mesocarpo de babaçu, sapucaia, xixá e castanha-do-pará por espectrometria de absorção atômica. Química Nova, 32(6), 1442-1446. https://doi.org/10.1590/S0100-40422009000600015

Thomson, C. D., Chisholm, A., McLachlan, S. K., \& Campbell, J. M. (2008). Brazil nuts: an effective way to improve selenium status. The American Journal of Clinical Nutrition, 87(2), 379-384. https://doi.org/10.1093/ajcn/87.2.379

Turner, R. C., Radley, J. M., \& Mayneord, W. V. (1958). The Naturally Occurring Alfa-ray Activity of Foods. Health Physics, 1, 268-275.

UNSCEAR, U. N. S. C. on the E. of A. R. (2000). Sources and Effects of Ionizing Radiation. (U. N. S. C. on the E. of A. R. UNSCEAR, Ed.) (First). New York: United Nations Pubns.

Venturini, L., \& Sordi, G. A. A. (1999). Radioactivity in a comitted effective dose from some Brazilian Foodstuffs. Health $\quad$ Physics, 76(3), 311-313. https://doi.org/10.1097/00004032-199903000-00013 


\section{Macrothink}

Journal of Agricultural Studies

ISSN 2166-0379 2020, Vol. 8, No. 2

Welna, M., Klimpel, M., \& Zyrnicki, W. (2008). Investigation of major and trace elements and their distributions between lipid and non-lipid fractions in Brazil nuts by inductively coupled plasma atomic optical spectrometry. Food Chemistry, 111(4), 1012-1015. https://doi.org/10.1016/j.foodchem.2008.04.067

WHO, W. H. O. (2006). GEMS/food consumption cluster diets.

Yang, J. (2009). Brazil nuts and associated health benefits: A review. LWT - Food Science and Technology, 42(10), 1573-1580. https://doi.org/10.1016/j.lwt.2009.05.019

\section{Copyright Disclaimer}

Copyright for this article is retained by the author(s), with first publication rights granted to the journal.

This is an open-access article distributed under the terms and conditions of the Creative Commons Attribution license (http://creativecommons.org/licenses/by/4.0/). 